\title{
The Perceptions of Foreign Language Pre-Service Teachers Towards Multicultural Education: Case of the Faculty of Education, TIU-Erbil, Iraq
}

\author{
Bunyamin Celik ${ }^{1}$ \\ ${ }^{1}$ Department of Languages, Tishk International University, Erbil, Iraq \\ Correspondence: Bunyamin Celik, Department of Languages, Tishk International University, Erbil, Iraq. E-mail: \\ bunyamin.celik@ishik.edu.iq
}

Received: October 16, 2019 Accepted: November 14, 2019 Online Published: December 15, 2019

doi:10.5539/ijel.v10n1p142 URL: https://doi.org/10.5539/ijel.v10n1p142

\begin{abstract}
This study was conducted to investigate the perceptions of pre-service teachers majoring in English at the department of English Language Teaching (ELT) - Tishk International University Education Faculty in Iraq at the level of knowledge and attitude. Studies related to the concept of multiculturalism are significant as being discussed recently in our globalized world and Mesopotamia in Iraq. The present study was planned in 20182019 academic year by using case study design within the framework of qualitative research method. The study was carried out with 90 final year students ( 48 females and 42 males). The subject participated in the study on a voluntary basis. The data of the study were obtained by using semi-structured interview technique. The data obtained from the study was collected under certain codes and themes by content analysis. As a result of the analysis of the data, it was determined that pre-service teachers had both right and wrong learning about the concepts of multiculturalism and multicultural education, and their attitude levels were both positive and negative. In this regard, it is thought that it may be beneficial for prospective teachers to receive a training in the vocational education process related to multiculturalism and multicultural education. Conducting the studies to be planned for multicultural education applications by revealing different variables will enable the subject to be evaluated from different perspectives and will be beneficial for the enrichment of the literature on the subject.
\end{abstract}

Keywords: multiculturalism, multicultural education, foreign language, English teacher

\section{Introduction}

Culture is a very difficult term to define. American anthropologists Kroeber and Kluckhohn (1952) critically examined the concepts and definitions of culture and compiled a list of 164 different definitions. The meaning expressed by culture has been compiled in this work for many researchers according to that time and revealed its differences until today. Today, according to many researchers, although the meaning of culture varies, the definition of famous anthropologists Spencer and Oatey (2008) are as follows: "Culture is a fuzzy set of basic assumptions and values, orientations to life, beliefs, policies, procedures and behavioral conventions that are shared by a group of people, and that influence (but do not determine) each member's behavior and his/her interpretations of the 'meaning' of other people's behavior." It is a generally accepted definition by many researchers and linguists. In general, culture consists of abstract thoughts, values, and world perceptions that give to people information about human behavior and come to life in these behaviors. Culture is shared by members of a community and produces patterns of behavior that can also be understood by members of that community (Maynard, 2002; Lillard, 2006; Schein, 2010). In this sense, economic and technological developments in the present century have led to the development of relations between people and have initiated a radical process of change and transformation in all fields. It is also stated that one of the main parameters that condition this process is globalization (Wise \& Velayutham, 2009; Freeman, 2010; Reinke \& Adams, 2011; Small-Clouden, 2016; Bishop, 2011). So much so that an event that happens anywhere in the world can be learned by people on the other end of the world in a very short time or instantly with the rapid development of communication technologies. Thus, the increasing communication speed between people has made culturally homogenous understanding of the nation-state fade away and countries have become multicultural (Wise \& Velayutham, 2009; Meer \& Modood, 2012; Cantle, 2012). 
In societies where people with different cultural characteristics live together, each community wants to maintain its own lifestyle, beliefs and cultural values and wants others to respect these values. Depending on this situation, whether individuals having different cultural background have the ability and awareness to live together or not has become one of the biggest problems of today's societies. This may, in fact, show how much society accepts democratic values. Because in a society where democratic values are experienced, every person's way of life is respected (Gay, 1994; Gutmann \& Ben - Porath, 2014). It is possible to conceptualize the idea of the legitimacy of the view that societies are a texture of differences as "multiculturalism" (Amin, 2002; Hatton, 2003; Haas, 2008). Again, the most commonly used definition in the literature about multiculturalism refers to awareness of race, ethnicity, language, sexual orientation, gender, age, disability, social class, religious orientation and other cultural dimensions (APA, 2003).

According to APA (2003), this awareness includes the ability of the individual to gain competence on both cultures without losing his/her cultural identity. Since there are differences in traditions and customs, institutions, political practices, values, thoughts and behaviors of each community, multicultural life requires that different desires be lived together under equal conditions (Amin, 2002). A multicultural life can be seen as understanding the differences in society and creating a common culture by ensuring the equality of the differences. What is meant here is not only respect for differences, but also the legal equality of these differences (Kymlicka \& Bashir, 2008). Multicultural societies can provide an effective communication and interaction environment in the process of creating this understanding, as well as experiencing conflict and depression. The Mesopotamia region where Iraqis one of the countries situated has been experiencing this interaction for thousands of years and has many experiences that have caused many agonies and shocks in the world history and culture as it is the first center of multicultural life. There was a consensus that multiculturalism was misperceived, and it became the main reason for the negativity. This has led to the search for ways to improve the social perception of multiculturalism in a positive way (Janssen \& Caroline, 1995).

As a result of this study, it has been necessary to adopt new values and approaches in education in order to perceive multiculturalism correctly. As a requirement of this necessity, the correct expression of multiculturalism through education of this diversity to the society and the restructuring of educational environments comes first. For centuries, in Iraqi lands which can be counted as the center of ancient Mesopotamia civilizations, different colors, languages, religions, cultures have lived together in different times. By taking into account the cultural interaction and necessity of coexistence over time, it will be possible to have a clear understanding of multiculturalism in order to regulate social life, educational environments and legal infrastructure in an egalitarian manner (O’Leary, McGarry, \& Salih, 2006; Alsultany, 2012).

\subsection{Statement of the Study Problem}

Today, the biggest conflict in Iraq emerges at this point. Despite a great and ancient history, the theoretical, academic and practical knowledge of multiculturalism is limited. One of the most important steps to correct this situation is to teach the concepts of multiculturalism and multicultural education correctly (Joppke, 2005). This process will only be possible with teachers and trained academicians in the role of training and practitioners.

As can be seen, the problem of multiculturalism has become one of the most frequently discussed issues in the world over the last decades. The fact that societies are multicultural in the process of erosion of the nation-state structure on the political and ideological level has brought multicultural education practices in many countries. As a result of these developments, it is seen that multicultural education practices are being discussed and examined in various aspects in academic level.

In addition, the basic element of culture is the language which assumes the function of a container that shapes emotions and thoughts and enables them to be carried from generation to generation. According to Celik and Yildiz (2019), culture is the life preserver and the elixir of life so as to preserve the existence of language and not to lose its dynamism. In this case, culture needs language to be transferred from generation to generation. Culture is also a need for language, which is the means by which society's emotions, thoughts, and literal manifestations of life become embodied. In this context, while language is the carrier of culture, culture is an important field of application which is the basis for showing the qualities of language. Language is embodied through concrete products through the perception, interest and cultural values of society. Everything that is the subject of speech is the reflection of culture to social life through language.

\subsection{Purpose of the Study}

The present study aims at investigating the perceptions of the prospective foreign language pre-service teachers towards multiculturalism and multicultural education concepts, as those teachers will be the identifier of a new language and therefore a new culture, especially to teach and guide the new generations of Iraq. In addition, it 
aims at developing education and practice as well as enriching the literature in educational pedagogy.

\section{Literature Review}

\subsection{The Role of Teachers and Pre-Service Teachers in Multicultural Education}

Multicultural education emerged in the United States in the 1960s with the civil rights movement. In the 1970s, with the development of the literature with the studies on differences, side areas that feed on multicultural education such as education for different ethnicities, education for cultural pluralism and education for equality emerged (Rizvi, 2012). Many researchers defined multicultural education as something that includes the experiences and cultures of students from different ethnic and cultural groups (Gorski \& Covert, 2010). According to Gay (2004), multicultural education is the equality of education for students of different sexes, students from different ethnic and cultural groups and students with disabilities. According to Mwonga (2005), it is an educational alternative and strategy and aims to correct existing inequalities. For this reason, education is defined as a prerequisite for the correct perception of multiculturalism and thus, the concept of multicultural education has emerged (Rapp, 2002; Furman \& Shields, 2005; Furman, 2012;). Multicultural education aims to provide equal educational opportunities for all students from different languages, races, ethnicities and social groups and to develop dialogue between different groups of students (Bohn \& Sleeter, 2000; Ladson-Billings, 2004; Banks, 2008; Banks, 2009).

Although the idea of multicultural education is increasingly accepted among educational scholars, it is stated that the current educational practices in schools are insufficient for students to develop positive attitudes towards different cultures. Brown and Kysilka (2002) stated that there are six components of education and training; teacher, student, environment, program, teaching and evaluation. They stated that the most important element among these variables is the teacher. Because, no matter how good the curriculum is, the teachers who implement the curriculum have a significant effect on students' sensitivity to different cultures. Teacher is an important part of the personal development of students as well as an important part of the education system. Therefore, teacher's stance, philosophical view and knowledge affect future generations (Day, 2002; Smith, 2009). In addition, people emphasize that teaching profession is basically "education of values". Students are also interested in attitudes and behaviors against events and situations that teachers tell. Therefore, teachers need to be open to all kinds of differences and plan their education by considering these differences (Gay \& Howard, 2000; Le Roux, 2000; McAllister \& Irvine, 2000; Banks, 2009; Smith, 2009). According to Cogan and Pederson (2001), the teacher of the 21 st century should be sensitive to all problems, from social, economic, cultural and environmental issues to the rights of citizens, to all kinds of country, nation and all humanity. According to Reiter and Davis (2011), student-teacher cultural mismatch in an increasingly diverse classroom environment leads to cultural and ethnic ignorance, and this is potentially dangerous. For this reason, it is becoming more and more important to train teachers who purify themselves from racist thoughts, who can stand at equal distance to everyone without distinction between language, religion and race, who know their own culture and who try to recognize students' cultures. It is believed that this understanding can be realized by the achievement of multicultural competencies of all teachers, especially those pre-service ones. In this context, it was suggested that teacher training programs should be revised to include multicultural education subjects (Szabo \& Anderson, 2009; Ensign, 2009). In recent years, it has been observed that some universities have structured their teacher training programs on the basis of multicultural education (Fox \& Diaz-Greenberg, 2006). In addition, it is stated that the education programs implemented in schools should be organized in a way to introduce multiculturalism to students in various dimensions (Quezada \& Romo, 2004). However, Miksch et al. (2003) find the idea that multicultural education should only be included in educational programs insufficient. They also advocate that multicultural education should be structured under the theme of multiculturalism as a whole, which transcends classroom practices. On the other hand, it was concluded that the upbringing of teachers in multicultural education prior to their professional life contributed to their positive attitude towards multicultural education (Cho \& DeCastro-Ambrosetti, 2005; Al-Haj, 2005; Fox \& Diaz - Greenberg, 2006; Al-Mohd \& Ahmad, 2009; Atta-Alla, 2012). In another study, it was determined that the newly started teachers thought that it would be beneficial to receive training on multicultural education before starting their career (Gasbarro \& Matthews, 1994; Lacina \& Sowa, 2005; Elhoweris, 2008). In a study examining the perceptions of experienced and inexperienced teachers about multicultural classes, it was found that both groups did not have enough information about cultural diversity in the classes (Gormley, McDermott, Rothenberg, \& Hammer, 1995; Akl, 2007). On the other hand, it was understood that teachers who developed mutual understanding and self-confidence had positive attitudes towards students of different ethnicity in the classroom (Lacina \& Sowa, 2005; Al-Mohd \& Ahmad, 2009; Smith, 2009). 


\section{Methodology}

This study was conducted in accordance with the qualitative research approach, the case study method (Mcmillan \& Schumer, 2006) was used and content analysis was conducted. The aim of this type of analysis is to reach the concepts and relationships that can explain the obtained data. The data is summarized and interpreted in the descriptive analysis and subjected to a deeper processing in the content analysis. Concepts and themes that cannot be noticed in descriptive analysis can be discovered as a result of this analysis (Creswell \& Creswell, 2017)

\subsection{Subject}

The study group consisted of 90 volunteer pre-service teachers (48 females and 42 males) who are senior students in English Language Teaching (ELT) at Tishk International University Education Faculty in Iraq. This study was conducted with the assumption that each language is a culture and a mirror of society cultures. Foreign Language Curriculum in which cultural transfer, equality, tolerance and multiculturalism are handled more intensely than other curriculums were the determining factor in the selection of the study group. While teaching their students a new language, they also present a new culture and perspective to them. In this respect, the education of pre-service teachers in line with the teaching profession was taken into consideration and only senior students were included in the study group.

\subsection{Tool of Data Collection}

In the study, semi-structured interview form was used as data collection tool. In the process of preparing the semi-structured interview form, the literature was searched for reliability and validity. 13 open-ended questions were prepared by examining the obtained documents. The open-ended questions were examined by an assessment specialist and an educational sociologist at the Tishk International University Education Faculty. The prepared questions were distributed to targeted subject and asked to fill out. After completing the forms, the answers of the pre-service teachers to the questions were examined and seven questions which were most appropriate for the purpose of the interview and the purpose of the study were considered.

\subsubsection{Questions of the Interview}

1) What is culture and how do societies provide cultural accumulation and transference?

2) What do you think about the concept of multiculturalism?

3) What emotions does multiculturalism stimulate in you?

4) What do you think about the concept of multicultural education?

5) Our university has been studying for 4 years with students from many different cultures and societies due to geographical reasons and being an international university. What are the positive and negative aspects of your education in a multicultural environment for your professional and personal development?

6) If you have an extraordinary experience during your education at our university in a multicultural environment, can you share what briefly?

7) What do you think about the applicability of multicultural education in the Iraqi education system?

Interviews with prospective teachers were formed with four basic questions and further investigations during the interview and data were obtained.

\subsection{Analysis of Data}

The data obtained during the study process was subjected to content analysis and brought together under certain themes and categories. The themes of knowledge and attitude related to the concepts of multiculturalism and multicultural education were determined and the frequency values under these themes were expressed in the tables together with the explanations of the categories and examples of these categories. In addition to the researcher, the opinions expressed by the prospective teachers during this application were also examined by a different assessment and evaluation specialist, educational sociologist and qualitative research specialist within our university. According to the results of this comparison, the determined codes and themes were found to be similar up to $75 \%$. The reliability $=$ Consensus/Consensus + Disagreement X 100 formula was applied on the coding made by researchers and readers for reliability (Miles \& Huberman, 1994). The agreement between the two encoders was calculated as $77 \%$. As the percentage of agreement was found to be $70 \%$ or more, reliability was obtained in terms of data analysis. 


\section{Findings and Discussion}

The findings obtained as a result of the analysis of the data obtained during the study process are presented at the level of knowledge and attitude.

Table 1. Prospective teachers' knowledge levels on the concepts of culture and multiculturalism

\begin{tabular}{llll}
\hline Level of Knowledge & Correct Knowledge & Equal view of global differences & F \\
& & Regionally different applications of National Culture & 7 \\
& Globalization and cultural exchange & 8 \\
& Wrong Knowledge & Cultural differences in the same region & 49 \\
& & The disappearance of national culture & 2 \\
& & Political Movement & 3 \\
& Literacy & 5 \\
& Cultural Heritage & 8 \\
\hline
\end{tabular}

Table 1 presents the findings of pre-service teachers' level of knowledge about the concept of culture and multiculturalism. When the literature on multiculturalism is examined, the most accepted definition of the concept is given as follows: "Multiculturalism is awareness of language, religion, race, gender, age, social class, ethnicity, disability and other cultural values AP" (APA, 2003). Based on this definition of multiculturalism, pre-service teachers' statements were examined, and it was observed that they had both correctly and incorrectly learned about multiculturalism. Pre-service teachers who have the correct knowledge of multiculturalism used expressions such as: language, religion, race, lifestyle, long-term relationships with different cultures, and the guarantee of cultural differences by law. Regarding the findings, prospective teachers who participated in the study made the following explanations:

Candidate teacher 1: "Culture is a common reaction to the experiences of people living together in a particular region, whether small or large, in the life cycle. Culture is also the common habits that people generally accept in their lifestyles. Multiculturalism refers to the fact that different groups of people living in the same geographic area react differently to the experiences they encounter as a group and have different life habits than the other group of people in the region."

Candidate teacher 2: "Multiculturalism refers to different groups of people living in the same community. These communities may differ in whole or in part in terms of language, religion, race, and lifestyle. Although there is a common language in society, different languages may be spoken locally. Multiculturalism is often seen in a province, a district or even in a village, as it would emerge within the boundaries of a state."

Candidate teacher 3: "Culture is called the whole of customs and traditions in the field where people live from the past to the future. Multiculturalism, on the other hand, occurs when societies around the world come together for different reasons and react differently to any experience or phenomenon. The main differences are language, religion and race. I also believe that with the increase in technology and the ability to receive news in the globalizing world, human beings will lose a part of their national culture and will have a common world culture due to intense interaction."

Candidate teacher 4: "Culture is habits inherited from people's ancestors. Multiculturalism emerges as a result of the interaction of different communities within a geographical location. Thus, the interaction of different cultures is born. Different lifestyles, clothing, dressing, eating and drinking, race, language, religion, sectarian differences can be listed as examples of multiculturalism."

On the other hand, prospective teachers who had misconception about culture and multiculturalism explained the concept as follows: Cultural accumulation in the historical sense, which includes mostly material elements, the search for dominance of prevailing cultures over other local cultures, a method used by different political elements to gain interest, and to have general knowledge about different cultures.

Moreover, some of the statements of prospective teachers examined to reach these findings are given below.

Candidate teacher 1: "When I say culture or multiculturalism, I think of having knowledge about the cultures of different societies or civilizations, especially our culture. Multiculturalism is to know different opinions, different thoughts, different traditions and customs".

Candidate teacher 2: "The concept of culture is called different activities that are created between people in a 
certain region. Multiculturalism, on the other hand, is the accumulation that has been transferred from generation to generation that can change over long distances and that has been going on for a long time."

Candidate teacher 3: "Multiculturalism is a society's development of its own culture over time to acquire new cultures and customs. In addition, other societies in the world will benefit from multiculturalism by enriching their own culture".

Table 2. Findings on the attitude level of the candidate teachers who have the right knowledge regarding the concept of multiculturalism

\begin{tabular}{llll}
\hline & & & F \\
\hline Attitude Level & Those with positive attitude & Peace and Freedom & 9 \\
& & It causes cultural tolerance and diversity & 47 \\
& Those with negative attitude & Anxiety and conflict & 5 \\
& & The fear of assimilation & 11 \\
\hline
\end{tabular}

In Table 2, pre-service teachers' attitudes towards multiculturalism are given. However, these statements reflect the views of prospective teachers (72) who have accurate information about the concept of multiculturalism. As it was observed that the attitudes and expressions of pre-service teachers (16) who had incorrect information about the concept changed according to their perception of the concept of multiculturalism, their attitude level expressions are given in Table 3.

It was seen that most of the pre-service teachers' attitudes towards multiculturalism (78\%) were positive and a small part (22\%) were shaped negatively. When the statements of the prospective teachers who have positive attitudes towards multiculturalism were examined, it was observed that the idea of living together and the creation of a peace environment and everyone living their own culture were seen as the most natural rights. In order to reach these findings, some excerpts of prospective teachers are given below.

Candidate teacher 1: "I think multiculturalism is a great wealth and beneficial to the sociological development of society. I believe that it is a positive concept for Iraqi society. For Iraqi society, differences mean cultural richness. As a matter of fact, Iraqi society has a multicultural structure due to the fact that both the geography and the Mesopotamian societies have a wide range. Languages, lifestyles and different beliefs are the biggest examples of this situation. So, multiculturalism is a good thing and should be supported."

Candidate teacher 2: "The geography of Mesopotamia, which is considered the birthplace of the world and cultures, is the first land where multiculturalism took place in history. The Iraq in its center hosts people from many different cultures, religions and races. These communities, which have lived together for hundreds of years, have managed to keep their culture alive to the present, even though they sometimes have problems. The reason for this is that they have understood what multiculturalism means from their positive and negative experiences in time. Every color and pattern in Iraq are a source of gain and pride for this geography. It is the realization of freedom and tolerance."

Candidate teacher 3: "We can actually consider multiculturalism as a national culture. Because our society is not only composed of individuals of Arab origin, or on the contrary, of Kurdish origin. In this society, Kurd, Ezidi, Kakai, Arab and Turkmen have lived together and continue to live. Together with these people, they lived their cultures and even continued to reflect on each other's lives. In essence, we can think of Iraqi culture as a mixture of all these rather than water, flour, yeast and salt. In other words, for our society, multiculturalism is a symbol of freedom and wealth".

When the statements of prospective teachers with negative attitudes towards this concept (16) were examined, it was concluded that creating a chaos environment by using cultural differences could lead to separation in the family, school, street and the idea of living together would be possible only with a national culture. Pre-service teachers stated that respect for cultural differences is of course a need for beautiful and diverse societies, but they are concerned that this may be misused. In order to reach these findings, some statements of prospective teachers are given below.

Candidate teacher 1: "Many multicultural countries or communities in the West have created this environment with concepts such as understanding, tolerance and respect. Multiculturalism can vary from one's perspective. In Iraqi society, when I say multiculturalism, I think of assimilation and getting away from the Arab identity. Because we take everything that culture envisages, not culture, and replace it with our original culture. I think that we cannot protect our essence by putting our national values in the background. These habits from our 
ancestors that make us who we are will only make us superior."

Candidate teacher 2: "Iraqi society is the most obvious example of multiculturalism. However, it is possible to see the positive and negative effects of this. Gathering under a flag without discrimination of language, religion and race is both a great wealth and the best example of unity and solidarity. However, it is inevitable that some of the interest groups will try to disrupt this unity and want to achieve their goals by breaking these ethnic groups within Iraqi society. I think we should be careful about multiculturalism in Iraq. This issue can also lead to separation."

Candidate teacher 3: I accept that multiculturalism is a richness and today, thanks to technology, it is a great interaction environment. But we are the people of Mesopotamia and children of societies that have lived in constant conflict and constant anxiety in our history. Therefore, I think that, besides the positive situation that multiculturalism will bring, it also leads us to different concerns due to our bitter experiences in the past. As a matter of fact, I believe that the Arab culture and customs which are more dominant in the central administrations will be more beneficial. But all societies and cultures must have equal rights in education and social life.

It can be said that the attitudes of prospective teachers (56) who have the correct information about the concept of multiculturalism are generally positive. However, the statements of the prospective teachers (16) with negative attitudes predict situations that should be seriously examined. In particular, the fact that prospective teachers who have negative attitudes about the concept gave examples from Mesopotamian history is important not only in terms of showing the dimensions of the effects of historical events to the present day, but also to show that the opinions of prospective teachers are based on a realistic basis.

Table 3. Findings related to the level of attitudes of prospective teachers who have wrong information about the concept of multiculturalism

\begin{tabular}{llll}
\hline & & & F \\
\hline Level of attitude & Those with positive attitude & Usefulness-diversity & 12 \\
& Those with negative attitude & Fear of assimilation & 4 \\
\hline
\end{tabular}

In Table 3, the attitude expressions of the prospective teachers who have misleading (16) about the concept of multiculturalism are given. When the statements of prospective teachers who have positive attitude (12) were examined, it was seen that they expressed multiculturalism as cultural wealth (concrete cultural heritage). The pre-service teachers who stated that Iraq had this privilege because of being in the center of Mesopotamia stated that being multicultural is beneficial for the people of every country. On the other hand, prospective teachers with negative attitudes (4) experienced the fear that national culture might disappear. Some examples of the expressions of prospective teachers examined to reach these findings are given below:

Candidate teacher 1: "The great powers of the world have stated that the way to destroy Iraq is to remove them from their own culture and to create conflicts between different societies. I think multiculturalism serves this purpose. All different cultures living in these lands are actually a potential danger to each other. In my opinion, Iraqi society needs to attach more to its own culture than ever before."

Candidate teacher 2: "Multiculturalism should be handled in a very different way for Iraqi society because the geography of Mesopotamia has been the bridge of civilizations. It is home to many ancient and different cultures. We cannot say that there is only one culture; each province has different cultures, customs and lifestyles. Multiculturalism in Iraqi society dates back to many years. I think that the culture of Iraqi society exists in the whole geography of Mesopotamia because our culture is so old and noble and because our history goes back to long and very ancient years."

Table 4. Prospective teachers' knowledge levels on the concept of multicultural education

\begin{tabular}{lll}
\hline Level of knowledge & Correct knowledge & Ensuring Equal Opportunity in Education \\
& Universal Education & Introduction of cultural diversity to the curriculum \\
& Respect for Cultural Differences and Tolerance Training \\
& Wrong knowledge & International student exchange \\
& To teach national unity \\
& Introducing different cultures to society \\
\hline
\end{tabular}


Table 4 shows the level of knowledge of pre-service teachers (90) who participated in the study on the concept of multicultural education. When literature about what is multicultural education is examined, the most accepted definition of the concept is given as follows: Multicultural education aims to provide equal educational opportunities for all students from different races, ethnicities and social groups and aims to develop dialogue between different student groups (Quezada \& Romo, 2004; Kymlicka \& Bashir, 2008; Banks, 2008; Wise \& Velayutham, 2009; Meer \& Modood, 2012).

When the statements of the prospective teachers are examined according to the definition given above, it is seen that they have both correct (75\%) and incorrect knowledge (25\%) about multicultural education. It was seen that pre-service teachers (67) who have the correct information about the concept perceived multicultural education as follows:

- Teaching that differences are natural.

- Since education is a universal phenomenon, culture should be taught in accordance with universal principles.

- Cultural differences should be included in the textbooks and equality of opportunity in education should be ensured.

Some of the statements of prospective teachers examined to reach these findings are given below.

Candidate teacher 1: "Indeed, the Middle East covers a very large geographic area. In Iraq, our national culture should be transferred in a way to form a whole together with regional cultural features. Even if different cultures are considered, culture should be included in the education program, far from nationalism. We must teach our students that cultural differences are a natural situation and that everyone should respect the culture of the other. This training should not be on a personal basis. A professional curriculum should be prepared with state policy and I think it should be implemented not only in schools but also in all social and public areas".

Candidate teacher 2: "Our country is rich in culture and cultural life. Many different races, religions, even different denominations within the same religion, many different societies and cultures have been living in our country for many years. Therefore, in terms of multicultural education system, it is an issue that should be dealt with in the curriculum in every subject. We can say that although both of them are Muslims, the culture of a "Shia" and "Sunni", or Kurdish and Arab, is not the same. These differences should be communicated to the student, explaining that this is a natural thing and also a wealth for both him and his country."

Candidate teacher 3: "I think that multicultural life is our destiny. My father a Kurdish Muslim and my mother was a Christian Assyrian. My grandmother is an Arab and a Muslim. Although the cultural background of our whole family is different, we have lived together peacefully for many years. Sometimes family members contradicted each other in different subjects and their relationships were negatively affected. However, when the subjects were examined, they realized that they had very small and simple solutions. In this context, if the elders in my family had knowledge of multiculturalism and multicultural education during school years, perhaps none of these minor problems would have occurred. States like us, having a multicultural society, must have education policies that take universal values into consideration."

Candidate teacher 4: "Multicultural education can be compared to individual differences. Just as students" learning speeds and comprehension capacities are different, their cultures can be different. In addition, each person's perception and reaction to events are different. We believe that if we can combine these perceptions with universal values in cultural interactions, we can control possible problems or misperceptions. For example, as our teachers take into account individual differences in the classroom and behave in this direction, they should take the same sensitivity into cultural differences. In doing so, students should be able to show that this is a cultural wealth and the importance of multicultural education. In other words, multicultural education is, in my opinion, to ensure that everyone can find their own cultural components in the classroom and have the others respect it."

On the other hand, prospective teachers who have misinformed about the concept of multicultural education (23) perceived the concept as a program created to provide language unity, cultural exchange formed through learning programs of different cultures such as Erasmus, Comenius. Some of the statements of the prospective teachers examined in order to reach these findings are given below.

Candidate teacher 1: "Multicultural life and education is a consensus in which people understand each other correctly. In my opinion, multicultural education is to achieve language unity. There are many different languages in Iraq. However, if all people accept Arabic as a common language and speak it, it will be easier for cultures to understand and recognize one another. Many Arab states in the world use a common language and solve many problems faster." 
Candidate teacher 2: "Multicultural education is a system based on the interaction of societies with each other. For example, there are student exchange programs today such as Erasmus, Socrates, Comenius or the education of students with sufficient financial resources in different countries ... They provide multicultural education. Students going abroad learn about their culture and even play a role in their change. For example, in Iraq, due to wars in the past, many people went to other countries and came back after a while. Those students were influenced by their culture and when they came back, they influenced their culture in a different way."

Candidate teacher 3: "Multicultural education is a form of education that takes into account the different needs of students from different cultures. In this context, all cultures that are different should be introduced in the curriculum and explained to students who have different cultures. Thus, a multicultural education environment is provided for all our students."

Table 5. Findings on the attitude level of the candidate teachers who have the correct knowledge regarding multicultural education

\begin{tabular}{lll}
\hline $\begin{array}{l}\text { Level of } \\
\text { Attitude }\end{array}$ & Applicable & $\begin{array}{l}\text { Any person from all religions, sects and languages have the right to learn the culture of } \\
\text { their own. } \\
\text { It is not objectionable to teach respect and tolerance to cultural differences. } \\
\text { Not applicable }\end{array}$ \\
$\begin{array}{l}\text { It contradicts the logic of the nation-state, causes the national culture to be forgotten, } \\
\text { causing more segregation. } \\
\text { Conditionally } \\
\text { applicable } \\
\text { Not applicable for } \\
\text { now }\end{array}$ & $\begin{array}{l}\text { First of all, education should be given on the basis of national culture, then } \\
\text { multicultural education should be started and no one should abuse this situation. } \\
\text { There are those who will use this situation for their own benefit; a dependable } \\
\text { environment is to be provided. }\end{array}$ \\
\end{tabular}

Table 5 presents the findings regarding the attitudes of prospective teachers (67) who correctly define the concept in terms of applicability of multicultural education. When Table 5 is analyzed, it is seen that half of the pre-service teachers $(50 \%)$ who have the correct information stated that multicultural education practices are generally applicable to the Iraqi education system. On the other hand, it was observed that some of the prospective teachers $(31 \%)$ considered the practice of multicultural education to be applicable under some conditions and in certain limited periods for Iraq. Few of the prospective teachers $(6 \%)$ stated that multicultural education should not be implemented. It can be said that teacher candidates generally perceive multicultural education as a right (81\%). Some pre-service teachers $(13 \%)$ think that multicultural education should be implemented under certain conditions and they think that teaching national culture is a prerequisite.

On the other hand, teacher candidates who think that it is not the right time for the implementation of multicultural education are of the opinion that an environment of trust should be created. They also made it clear that they were uncomfortable with the presence of people who could use this situation to create an atmosphere of conflict and chaos. On the other hand, prospective teachers who stated that multicultural education could not be applied stated that this situation is contrary to the logic of nation-state and in this case the national culture would be damaged and the separation would be realized faster. Generally speaking, it is seen that pre-service teachers who have the right information have positive views on multicultural education. It can be said that prospective teachers who see the current situation as conditionally applicable and inapplicable are concerned that the national culture may be harmed. Some of the statements of prospective teachers examined in terms of reaching these findings are given below.

Candidate teacher 1: "Multicultural education practices should be prepared by the Iraqi Ministry of Education and included in our education system. Because it is now a criterion to include differences in contemporary education. In this way, individuals and therefore societies get rid of selfishness and become a contemporary tolerant union. The coexistence of different cultures requires universal values, tolerance and respect. Therefore, it should be included in all social areas, especially in school education."

Candidate teacher 2: "Multicultural education should take place within the education system of our country. However, the core cultural elements of the Iraqi state and the issues of national culture should be taught primarily to all students in a systematic way. The understanding of multiculturalism should only be given to children as a value in terms of respect for students with different characteristics in terms of different languages, religions and race. The necessity and importance of this is that the first condition for living together and serving this country is that everyone should respect each other's culture and accept them with their differences." 
Candidate teacher 3: "I think it takes some time to implement multicultural education in Iraq. First of all, the country has historical problems to solve and bad experiences in recent years. Only after a systematic and efficient orientation and rehabilitation program throughout the country can it be implemented comfortably. Because I think there are people or groups who can abuse this situation and cause negativity and even new conflicts. In particular, as I have already declared, the wars that have taken place in Iraq in recent years and the feelings worn out by these wars can only be restored by serious and systematic rehabilitation."

Candidate teacher 4: "To be frank, I think multicultural education is against the logic of nation-state. If there is no logic of a dominant nation and state for a country in any geography, multiculturalism brings harm and destruction rather than benefit. In fact, everyone is already experiencing their own culture. Everyone believes in the religion they want and speaks the language they want at home. I believe that multiculturalism and other expressions close to this conception are only things that have been put forward to destroy the national culture and real self of a state."

Table 6. Findings regarding the attitude level of multi-cultural education of prospective teachers with incorrect information

\begin{tabular}{lll}
\hline & & F \\
\hline Level of attitude & Applicable & Teaching the knowledge of different cultures is important for society. \\
& & $\begin{array}{l}\text { It is beneficial for intercultural dialogue development and information exchange. } \\
\text { The teaching of national culture is of vital importance and is as important as the basic education. }\end{array}$ \\
\hline
\end{tabular}

Table 6 presents the findings of the attitudes of prospective teachers (13) with misinformation towards multicultural education. It was seen that all the teacher candidates used the same expressions. It is seen that all of the attitudes of the pre-service teachers whose learning about the concept is wrong developed in a positive way. They think that multicultural education will be beneficial to society. Some of the statements of the prospective teachers examined to reach these findings are given below.

Candidate teacher 1: "Of course, it is very important for people to learn different cultures in addition to the culture they belong to. Today, only people who learn their own cultural values become weak from the point of view of the world and general knowledge. Therefore, multicultural education is a necessity in a sense and should be implemented in our education system as the state deems appropriate, and teachers should express this situation very well in schools and classroom environments."

Candidate teacher 2: "I think that the implementation of multicultural education within the curriculum is certainly very useful. It can be applied not only in basic education level but also in graduate and undergraduate education programs. In addition, both national and international student exchanges are very important for the fusion of cultures. For example, some of our friends from the class went to Turkey or different European countries for various reasons. Some of them are still there and some have returned. We talk to them every once in a while, and learn about their lives there. They told us that the people there had a very different life from here ..."

\section{Conclusion and Suggestions}

The aim of this study was to investigate the perceptions of the pre-service teachers in the department of English Language Teaching (ELT) on the concept of multicultural education at the level of knowledge and attitude. The results of the studies conducted in the literature are the most important factors for the success of multicultural education and the desired efficiency. Especially in societies where the understanding of multicultural education has just started to be discussed, the teacher is in a critical position. As a result of the education of the teacher candidates, it is expected that the students will create a democratic learning environment by respecting the cultural differences, although it is expected that they will be able to create behavioral changes appropriate to the profession in the cognitive, affective and psychomotor domains (Wise \& Velayutham, 2009; Szabo \& Anderson, 2009; Abrams \& Gibson, 2007; Furman \& Shields, 2005; Mildred \& Zúñiga, 2004).

The most important factor in the selection of prospective foreign language teachers in the study is that the perception of pre-service teachers who will teach a new language and therefore a new culture in the Iraq, which is the center of the Mesopotamian geography which has many languages and cultures, is higher than many other branches. Of course, the study in a multicultural geography has clearly demonstrated the process and experiences of the subject during their education. In this context, the results clearly showed that the prospective teachers who are already living and being educated in a multicultural environment have an effect on the perceptions of their 
own experiences as well as the academic courses they take in the university. However, when the findings obtained from the study were evaluated in general, it was understood that the teachers had a positive attitude towards multicultural education and found themselves sufficient to recognize their own culture and other cultures and to employ this knowledge in the process of learning and teaching.

In this study, perceptions of prospective teachers about concepts were investigated under the headings of knowledge and attitude. When the findings related to the level of knowledge were evaluated, it was seen that prospective teachers had both correct and incorrect learning about the concepts of multiculturalism and multicultural education.

The majority of the teacher trainees did not receive a multicultural education during the vocational education process. Although they are only academically exposed to concepts during university education, it is pleasing that they have a positive posture in terms of knowledge and attitude. In addition, it was observed that there were a small number of pre-service teachers who did not have the correct knowledge about the concepts. In this case, the first suggestion is that in all faculties of universities, especially in the faculties of education, a planning for multiculturalism and multicultural education should be applied to the academic curriculum. When the studies conducted by the researchers in this field are examined, it is seen that the prospective teachers who took the multicultural education course showed positive changes against the differences (Diego, 2013; Valentiin, 2006). Moreover, according to our study, it was seen that the situation that occurred in the perception of correct and incorrect concepts directly affected the attitudes of the prospective teachers in any way. It has been observed that the attitudes of the prospective teachers changed according to their perception of the concept. Therefore, in this study, the findings related to the attitude levels of prospective teachers who perceive the concept correctly and the teachers who perceive it incorrectly are evaluated separately. From this point of view, a second suggestion is as follows: The lecturers who express these concepts in the university should be very careful and provide them with the opportunities where they will gain extra education and experience related to the concepts. It was seen that the attitudes of the pre-service teachers who had the correct information about multiculturalism and multicultural education developed positive concepts such as tolerance, wealth, peace, freedom and negative concepts such as anxiety and fear, assimilation, conflict, chaos. It has been observed that prospective teachers who have positive attitudes regard multiculturalism and multicultural education as a basic right. It was observed that prospective teachers with negative attitudes experienced anxiety and fear, and therefore, they saw multiculturalism and multicultural education as a discriminating and disintegrating element. Similar results have been obtained in different studies conducted on the subject. Studies on multiculturalism in Iraq have been shaped by the fact that there are two opposing poles, generally advocating and not advocating multiculturalism (Alsultany, 2012; Harrison, 2008; O’Leary, McGarry, \& Salih, 2006). As mentioned above, it has been determined that the attitude levels of prospective teachers who have incorrect information about multiculturalism and multicultural education vary according to their perception of the concept. It was determined that the pre-service teachers who perceived the concepts as a useful application out of their real meaning had positive attitudes, and the pre-service teachers who perceived the concepts as damaging had a negative attitude. At this point, the study poses two main problems. The first is the fact that prospective teachers have problems in understanding the concepts of multiculturalism and multicultural education correctly. The second is that prospective teachers who perceive the concepts correctly have positive and negative views as far as their attitude is concerned. As a matter of fact, it is seen that the situation that emerges in terms of attitude expressions is consistent with the literature. Gutmann and Ben-Porath (2014), Meer and Modood (2012) and Ensign (2009) reported similar statements. It is important that multiculturalism and multicultural education are taught correctly in the first place. At this point, a third proposal is that the process of learning and teaching in multicultural education needs to be built in a common agreement to promote cultural pluralism and ensure respect for different cultures. It would be more efficient for the system and curriculum designers to take this into account and set curricula in this direction. Within the framework of this understanding, multicultural teacher training is also gaining importance. Furthermore, issues such as human rights, democracy education, and democracy in schools, implementation of multicultural education can be handled as a discipline or interdisciplinary approach in order to ensure that teacher trainees are sensitive to democracy and multiculturalism.

On the other hand, the necessity of acquiring knowledge and skills for multiculturalism has emerged for the teachers who are still working as teachers. A fourth proposal in this context is as follows: In this process, a systematic training program should be established through in-service training in order to develop the concepts of multiculturalism and multicultural education for the existing teachers within the ministry. For example, seminars, panels and workshops can be organized at specific intervals for multicultural education for teachers, and these studies can be supported interactively by teaching materials such as sample lesson plans, lecture videos, 
simulation and written materials containing cultural diversity. Another suggestion in this regard is to prepare teacher candidates for multicultural education and training environments and to gain experience. For this purpose, in coordination with the Ministry of National Education and universities, instead of paid teaching in some regions, teachers or prospective teachers who take teaching practice courses under the same conditions can be provided to take classes for a period in schools in different cultural regions. Based on the assumption that the impact of the phenomenon of multiculturalism and consequently the multicultural education initiative may increase gradually in the coming years, a fifth suggestion is that studies focusing on multicultural education at different levels of education are needed. It is advisable to identify the views and attitudes of different groups such as managers, students and parents in possible multicultural education researches. In addition, due to the fact that multicultural education is a multifaceted and sensitive issue, in-depth analysis of participants' views with qualitative approaches can make significant contributions to the field.

\section{References}

Abrams, L. S., \& Gibson, P. (2007). Teaching notes: Reframing multicultural education: Teaching white privilege in the social work curriculum. Journal of Social Work Education, 43(1), 147-160. https://doi.org/10.5175/JSWE.2007.200500529

Akl, L. (2007). The implications of Lebanese cultural complexities for education. Mediterranean Journal of Educational Studies, 12(2), 91-113 https://www.um.edu.mt/library/oar//handle/123456789/20187

Al-Haj, M. (2005). National ethos, multicultural education, and the new history textbooks in Israel. Curriculum Inquiry, 35(1), 47-71. https://doi.org/10.1111/j.1467-873X.2005.00315.x

Al-Mohd, A., \& Ahmad, M. (2009). Minority education and curriculum in the multilingual and multicultural society of the UAE. Doctoral dissertation, Durham University. Retrieved from http://etheses.dur.ac.uk/2923/

Alsultany, E. (2012). Arabs and Muslims in the Media: Race and Representation after 9/11. Nyu Press.

American Psychological Association. (2003). Guidelines on multicultural education, training, research, practice, and organizational change for Psychologists. American Psychologist, 58(5), 377-402. https://doi.org/10.1037/0003-066X.58.5.377

Amin, A. (2002). Ethnicity and the multicultural city: living with diversity. Environment and Planning A, 34(6), 959-980. https://doi.org/10.1068/a3537

Atta-Alla, M. (2012). Egypt education system: a monocultural education in a multicultural society. Journal of Sociological Research, 3, 476-488. https://doi.org/10.5296/jsr.v3i2.2645

Banks, J. A. (2008). An introduction to multicultural education.

Banks, J. A., \& Banks, C. A. M. (Eds.). (2009). Multicultural education: Issues and perspectives. John Wiley \& Sons.

Bishop, T., Reinke, J. \& Adams, T. (2011). Globalization: trends and perspectives. Journal of International Business Research, 10(1), 117-130.

Bohn, A. P., \& Sleeter, C. E. (2000). Multicultural education and the standards movement: A report from the field. Phi Delta Kappan, 82(2), 156-161. https://doi.org/10.1177/003172170008200214

Brown, S. C., \& Kysilka, M. (2002). Applying multicultural and global concepts in the classroom and beyond. Boston, MA: Allyn \& Bacon.

Cantle, T. (2012). Interculturalism: The new era of cohesion and diversity. Springer. https://doi.org/10.1057/9781137027474

Celik, B., \& Yildiz, Y. (2019). The Role of Foreign Language Culture on Teaching the Language and Learner Motivation. International Journal of Social Sciences \& Educational Studies, 5(4), 150-161. https://doi.org/10.23918/ijsses.v5i4p150

Cho, G., \& DeCastro-Ambrosetti, D. (2005). Is ignorance bliss? Pre-service teachers' attitudes toward multicultural education. The High School Journal, 89(2), 24-28. https://doi.org/10.1353/hsj.2005.0020

Cogan, J. J., \& Pederson, P. V. (2001). The development of civic values: case study of the United States of America. International Journal of Educational Research, 35(1), 61-76. https://doi.org/10.1016/S0883-0355(01)00006-4

Creswell, J. W., \& Creswell, J. D. (2017). Research design: Qualitative, quantitative, and mixed methods approaches. Sage publications. 
Day, C. (2002). School reform and transitions in teacher professionalism and identity. International Journal of Educational Research, 37(8), 677-692. https://doi.org/10.1016/S0883-0355(03)00065-X

Diego, D. (2013). Teacher preparation, professional development, and long-term English learners. International Journal of Education, 5(4), 1. https://doi.org/10.5296/ije.v5i4.4140

Elhoweris, H. (2008). Teacher Judgment in Identifying Gifted/Talented Students. Multicultural Education, 15(3), 35-38. ERIC Number: EJ793902

Ensign, J. (2009). Multiculturalism in four teacher education programs: for replication or transformation. Multicultural Perspectives, 11(3), 169-173. https://doi.org/10.1080/15210960903116928

Fox, R. K., \& Diaz - Greenberg, R. (2006). Culture, multiculturalism, and foreign/world language standards in US teacher preparation programs: Toward a discourse of dissonance. European Journal of Teacher Education, 29(3), 401-422. https://doi.org/10.1080/02619760600795270

Freeman, R. B. (2010). Globalization of scientific and engineering talent: international mobility of students, workers, and ideas and the world economy. Economics of Innovation and New Technology, 19(5), 393-406. https://doi.org/10.1080/10438590903432871

Furman, G. (2012). Social justice leadership as praxis: Developing capacities through preparation programs. Educational Administration Quarterly, 48(2), 191-229. https://doi.org/10.1177/0013161X11427394

Furman, G. C., \& Shields, C. M. (2005). How can educational leaders promote and support social justice and democratic community in schools (pp. 119-137)? A new agenda for research in educational leadership.

Gassbaro, S., \& Matthews, D. (1994). New teachers' perceptions of the meaning of the term multiculturalism and their perspectives of the need for multiculturalism in preservice education. In American Educational Research Association Conference, New Orleans, LA.

Gay, G. (1994). A Synthesis of Scholarship in Multicultural Education. Urban Monograph Series. ERIC Number: ED378287.

Gay, G. (2004). The importance of multicultural education. The Curriculum Studies Reader, 315, 320.

Gay, G., \& Howard, T. C. (2000). Multicultural teacher education for the 21st century. The Teacher Educator, 36(1), 1-16. https://doi.org/10.1080/08878730009555246

Gormley, K., McDermott, P., Rothenberg, J., \& Hammer, J. (1995). Expert and novice teachers' beliefs about culturally responsive pedagogy. Paper Presented at American Educational Research Conference, San Francisco, April 18-22, 1995. ERIC Number: ED384599

Gorski, P., \& Covert, B. (2010). Defining multicultural education. Retrieved, 26, 12.

Gutmann, A., \& Ben - Porath, S. (2014). Democratic education. In The encyclopedia of political thought (pp. $863-875)$.

Haas, C. (2008). Citizenship education in Denmark: reinventing the nation and/or conducting multiculturalism(s)? London Review of Education, 6(1), 59-69. https://doi.org/10.1080/14748460801889902

Harrison, L. (2008). The End of Multiculturalism. The National Interest, 93, 88-96. Retrieved from http://www.jstor.org/stable/42897687

Hatton, K. (2003). Multiculturalism: narrowing the gaps in art education. Race, Ethnicity and Education, 6(4), 357-372. https://doi.org/10.1080/13613320332000146375

Janssen, C. (1995). Babil, the City of Witchcraft and Wine. The Name and Fame of Babylon in Medieval Arabic Geography, Mesopotamian History and Environment, Memoirs II. In L. De Meyer \& H. Gasche (Eds.), Mesopotamian History and Environment Series I Memoirs II. Ghent: University of Ghent (p. 272). Published by the University of Ghent. Retrieved from http://hdl.handle.net/1854/LU-249601

Joppke, C. (2005). Exclusion in the liberal state: The case of immigration and citizenship policy. European Journal of Social Theory, 8(1), 43-61. https://doi.org/10.1177/1368431005049327

Kroeber, A. L., \& Kluckhohn, C. (1952). Culture: A critical review of concepts and definitions. Papers of the Peabody Museum, 47(11), 1-223.

Kymlicka, W., \& Bashir, B. (Eds.). (2008). The politics of reconciliation in multicultural societies. OUP Oxford. 
Lacina, J. G., \& Sowa, P. (2005). Preparing for multicultural schools: Teacher candidates dialogue online with teachers from Egypt, Japan, Ghana, and the US. Teacher Education Quarterly, 32(1), 61-75. ERIC Number: EJ795304

Ladson-Billings, G. (2004). New directions in multicultural education. Handbook of Research on Multicultural Education, 2, 50-65.

Le Roux, J. (2000). Multicultural education: A new approach for a new south African dispensation. Intercultural Education, 11(1), 19-29. https://doi.org/10.1080/14675980050005361

Lillard, A. S. (2006). The socialization of theory of mind: Cultural and social class differences in behavior explanation. In A. Antonietti, O. Liverta-Sempio \& A. Marchetti (Eds.), Theory of mind and language in developmental contexts (pp. 65-76). New York: Springer.

Maynard, A. E. (2002). Cultural teaching: The development of teaching skills in a Maya sibling interaction. Child Development, 73(3), 969-982. https://doi.org/10.1111/1467-8624.00450

McAllister, G., \& Irvine, J. J. (2000). Cross cultural competency and multicultural teacher education. Review of Educational Research, 70(1), 3-24. https://doi.org/10.3102/00346543070001003

McMillan, J. H., \& Schumacher, S. (2006). Research in education: Evidence based inquiry. Boston: Brown and Company. ERIC Number: ED577250

Meer, N., \& Modood, T. (2012). How does interculturalism contrast with multiculturalism? Journal of Intercultural Studies, 33(2), 175-196. https://doi.org/10.1080/07256868.2011.618266

Miksch, K. L., Bruch, P. L., Higbee, J. L., Jehangir, R. R., \& Lundell, D. B. (2003). The centrality of multiculturalism in developmental education: Piloting the Multicultural Awareness Project for Institutional Transformation (MAP IT). Multiculturalism in developmental education, 5-13.

Mildred, J., \& Zúñiga, X. (2004). Working with resistance to diversity issues in the classroom: Lessons from teacher training and multicultural education. Smith College Studies in Social Work, 74(2), 359-375. https://doi.org/10.1080/00377310409517721

Miles, M. B., Huberman, A. M., Huberman, M. A., \& Huberman, M. (1994). Qualitative data analysis: An expanded sourcebook. sage.

Mwonga, C. (2005). Multicultural education: New path toward democracy, reenvisioning. Education and Democracy, 15, 1-16.

O’Leary, B., McGarry, J., \& Salih, K. (Eds.). (2006). The future of Kurdistan in Iraq. University of Pennsylvania Press.

Quezada, R., \& Romo, J. J. (2004). Multiculturalism, Peace Education and Social Justice in Teacher Education. Multicultural Education, 11(3), 2-11. ERIC Number: EJ783084

Rapp, D. (2002). Social justice and the importance of rebellious imaginations. Journal of School Leadership,12(3), 226-245. https://doi.org/10.1177/105268460201200301

Reiter, A. B., \& Davis, S. N. (2011). Factors Influencing Pre-Service Teachers' Beliefs about Student Achievement: Evaluation of a Pre-Service Teacher Diversity Awareness Program. Multicultural Education, 19(3), 41-46. ERIC Number: EJ955944

Rizvi, F. (2012). Multicultural Education. The Wiley-Blackwell Encyclopedia of Globalization. https://doi.org/10.1002/9780470670590.wbeog403

Schein, E. H. (2010). Organizational culture and leadership (Vol. 2). John Wiley \& Sons.

Small-Clouden, L. (2016). Globalization, assimilation, culture erasure: A review of trinidad and tobago. Journal of Organizational Psychology, 16(1). https://doi.org/10.33423/jop.v16i1.1805

Smith E. B. (2009). Approaches to multicultural education in preservice teacher education: Philosophical frameworks and models for teaching. Multicultural Education, 16(3), 45-50.

Spencer-Oatey, H. (Ed.). (2008). Culturally Speaking Second Edition: Culture, Communication and Politeness Theory. Bloomsbury Publishing.

Szabo, S., \& Anderson, G. (2009). Helping teacher candidates examine their multicultural attitudes. Educational Horizons, 190-197. Retrieved from https://www.jstor.org/stable/42923765

Valentiin, S. (2006). Addressing diversity in teacher education programs. Education, 127(2), 196-202. 
Wise, A., \& Velayutham, S. (2009). Introduction: Multiculturalism and everyday life. In A. Wise \& S. Velayutham (Eds.), Everyday multiculturalism (pp. 1-17). London: Palgrave Macmillan. https://doi.org/10.1057/9780230244474_1

\section{Copyrights}

Copyright for this article is retained by the author, with first publication rights granted to the journal.

This is an open-access article distributed under the terms and conditions of the Creative Commons Attribution license (http://creativecommons.org/licenses/by/4.0/). 